\title{
HUBUNGAN KOMUNIKASI DAN DUKUNGAN SOSIAL KELUARGA TERHADAP KEKAMBUHAN PASIEN SKIZOFRENIA DI POLI KLINIK RUMAH SAKIT JIWA TAMPAN PEKANBARU PROVINSI RIAU
}

\author{
Yecy Anggreny ${ }^{1}$, Sodry $^{2}$, Bayu Saputra ${ }^{3}$ \\ ${ }^{1}$ PSIK STIKes HTP, ${ }^{2}$ PSIK STIKes HTP, ${ }^{3}$ PSIK STIKes HTP \\ Program Studi Ilmu Keperawatan STIKes Hang Tuah Pekanbaru Jalan Mustafa Sari No 5 \\ Tangkerang Selatan Pekanbaru \\ Email : yecy_anggreny@yahoo.com
}

\begin{abstract}
Abstrak
Skizofrenia merupakan kelainan psikis yang menempati peringkat kedua dalam penyakit yang menyebabkan beban paling besar setelah penyakit jantung. Ada beberapa masalah yang dapat dialami oleh pasien Skizofrenia, diantaranya yaitu: kekambuhan. Hal yang sering menimbulkan kekambuhan tersebut yaitu komunikasi dan dukungan sosial keluarga kepada pasien Skizofrenia. Penelitian ini bertujuan untuk mengetahui hubungan komunikasi dan dukungan sosial keluarga terhadap kekambuhan pasien skizofrenia di Poliklinik Rumah Sakit Jiwa Tampan Pekanbaru, menggunakan jenis penelitian kuantitatif dengan desain cross sectional, dengan populasi adalah seluruh keluarga pasien skizofrenia dengan jumlah sampel sebanyak 100 orang. Pengambilan sampel menggunakan teknik Accidental Sampling. Alat pengumpulan data menggunakan kuesioner dan analisa data dilakukan secara univariat dan bivariat. Hasil uji chi square untuk komunikasi $\left(p_{\text {value }}=0,018<0,05\right)$ artinya terdapat hubungan, sedangkan untuk dukungan keluarga $\left(p_{\text {value }}=\right.$ $0,009<0,05)$ artinya terdapat hubungan. Disarankan bagi RSJ Tampan Pekanbaru dapat menerapkan kepada seluruh perawat untuk menggunakan komunikasi serta memberikan dukungan sosial yang baik kepada pasien skizofrenia. Selain itu memberikan edukasi kepada keluarga pasien tentang pentingnya dukungan sosial keluarga dan komunikasi yang baik untuk mengurangi tingkat kekambuhan pada pasien skizofrenia.
\end{abstract}

Kata kunci : Komunikasi, dukungan sosial keluarga, kekambuhan pasien skizofrenia

\begin{abstract}
Schizophrenia is a psychological disorder that ranks second in the disease that causes the greatest burden after heart disease. There are some problems that can be experienced by schizophrenia patients, namely recurrence. It often leads to such recurrence of communication and family social support to patients with schizophrenia. This study aims to determine the relationship of communication and social support of families on the recurrence of patients with schizophrenia in Polyclinic Hospital Pekanbaru Tampan Soul. This research type is quantitative with cross sectional design. The population of this study is the entire family with a sample of 100 people. Sampling using Accidental Sampling technique. The data collection tool using questioner and data analysis is done univariat and bivariat. Test result chi square for communication (Pvalue $=0,018<0,05)$ means that there is relationship, while for family support $(P v a l u e=0,009<0,05)$ means there is relationship. It is hoped that with this research can increase family knowledge about the way of communication and provide family social support to patients with schizophrenia.
\end{abstract}

Keywords : Communication, family social support and recurrence of schizophrenic patients

\section{PENDAHULUAN}

Skizofrenia merupakan ganguan jiwa yang menempati peringkat kedua dalam penyakit yang menyebabkan beban paling besar setelah penyakit jantung. Menurut World
Health Organization (WHO) (2010), jumlah penderita skizofrenia didunia tercatat kurang lebih 24 juta jiwa.

Skizofrenia lebih sering terjadi pada Negara industri dan terutama pada populasi 
Yecy Anggreny ${ }^{1}$, Sodry $^{2}$, Bayu Saputra ${ }^{3}$, Hubungan Komunikasi Dan Dukungan Sosial Keluarga Terhadap Kekambuhan Pasien Skizofrenia Di Poli Klinik Rumah Sakit Jiwa Tampan Pekanbaru Provinsi Riau

urban, serta pada kelompok sosial ekonomi rendah. Jumlah insidennya diperkirakan 1 per 1000 orang di Amerika Serikat (Wiramihardja, 2007). Hasil Riset Kesehatan Dasar (Riskesdas) tahun 2018, menunjukkan bahwa prevalensi gangguan jiwa pada penduduk Indonesia yaitu 7\%. Proporsi RT yang pernah memasung ART gangguan jiwa berat $14,3 \%$ dan terbanyak pada penduduk yang tinggal diperdesaan $(18,2 \%)$, serta pada kelompok ekonomi rendah 19,5\%. Berdasarkan data yang diperoleh dari Profil Kesehatan Provinsi Riau tahun 2015, angka penderita skizofrenia di Riau tahun 2014 tercatat 26.834 kunjungan dan mengalami peningkatan pada tahun 2015 hingga mencapai 27.111 kunjungan (Profil Kesehatan Provinsi Riau, 2015).

Jumlah angka penderita skizofrenia diatas, menunjukan masalah yang serius yang perlu mendapatkan perhatian. Hal ini dikarenakan pasien Skozofrenia kurang mampu mengenal lingkungan atau orang yang familiar dan mungkin menuduh anggota keluarga menjadi penipu (Stuart, 2006). Pada pasien skizofrenia dapat menimbulkan beberapa masalah, yaitu kekambuhan (Stuart, 2006).

Salah satu hal yang sering menimbulkan kekambuhan tersebut salah satunya adalah komunikasi keluarga kepada pasien skizofrenia. Komunikasi yang menyimpang dalam keluarga seperti dengan nada tinggi dan menyinggung perasaan pasien skizofrenia, hal ini sangat berpeluang untuk munculnya gejala kekambuhan pada pasien skizofrenia (Wiramihardja, 2007). Keluarga dari orang dengan skizofrenia menunjukan tingkat penyimpangan komunikasi yang lebih tinggi dibandingkan dengan keluarga yang tidak memiliki anggota keluarga dengan skizofrenia (Wiramihardja, 2007).

Menurut Stuart (2006), komunikasi yang baik yang didapat diterapkan kepada pasien Skizofrenia, seperti dengan berbicara dengan tanpa menghakimi, membantah atau menunjukkan kekeliruan pada pasien, mempertahankan kontak mata, tersenyum dan memasang wajah yang positif saat saling berkomunikasi, dan bersikap netral jika pasien tidak mau diajak bicara. Dukungan sosial yang baik dari keluarga sangat membantu penyembuhan pasien Skizofrenia. Dukungan sosial yang baik dari keluarga dapat berupa memberikan motivasi dan perhatian kepada pasien Skizofrenia, perhatian dapat berupa dukungan keluarga dalam memberikan obat kepada pasien Skizofrenia (Wiramihardja, 2007).

Menurut Nirwan, dkk, (2016), dengan judul dukungan keluarga dalam perwatan pasien gangguan jiwa dengan pendekatan health promotion model menyimpulkan bahwa persebsi keluarga tentang manfaat, kemampuan dalam merawat pasien dan faktor interpersonal memberikan pengaruh yang signifikan terhadap dukungan kelurga . Hal ini didukung oleh hasil penelitian yang dilakukan oleh Yunita (2013), di RSJD Puri Nirmala 
Yogyakarta, menyatakan bahwa terdapat hubungan antara pola komunikasi dengan frekuensi kekambuhan pasien skizofrenia. Selain komunikasi yang baik, dukungan sosial juga dapat mempengaruhi kekambuhan pasien Skizofrenia.

Menurut Rothrock (2009), dukungan sosial dari keluarga dapat mempengaruhi tingkat kekambuhan pasien skizofrenia. Pada umumnya pasien skizofrenia sering mendapatkan stigma dan diskriminasi dilingkungan sosialnya, hal ini sering menyebabkan pasien skizofrenia merasa tidak nyaman atau tertekan sehingga timbul kekambuhan pada pasien skizofrenia Rothrock (2009). Hal ini sesuai dengan penelitian Taufik (2009), dengan hasil terdapat hubungan dukungan keluarga dengan tingkat kekambuhan pasien Skizofrenia.

Beberapa keluarga yang memiliki anggota keluaraga yang mengidap skizofrenia, diharapkan ikut berperan dalam untuk membantu penderita semandiri mungkin dan menyesuaikan dengan segala ketidakmampuannya. Adanya komunikasi yang baik dan dukungan sosial dari keluarga akan memberikan perawatan kepada pasien Skizofrenia untuk pulih kembali dan dapat menjalankan fungsi dan perannya sebagai seorang individu, sesuai dengan tugas dan perkembangannya (Rothrock, 2009).

Berdasarkan survey awal yang dilakukan oleh peneliti terhadap 10 orang keluarga pasien skizofrenia yang melakukan rawat jalan, diperoleh informasi sebanyak 4 orang diantaranya mengatakan tidak pernah mengalami kekambuhan selama 5 bulan terakhir, sedangkan 6 orang lainnya mengaku bahwa pernah mengalami kekambuhan $\geq 2$ kali dalam kurun waktu 5 bulan terakhir. Hasil wawancara pada 6 keluarga yang anggota keluarganya mengalami kekambuhan mengatakan bahwa gejala kekambuhan tersebut seperti marah tanpa sebab, bahkan melempar barang-barang perabotan yang ada dirumah. Keluarga juga mengatakan mereka berbicara dengan meneriaki dan tidak mau menatap wajah anggota yang menderita Skizofrenia, selain itu mereka juga mengatakan bahwa mereka jarang mengingatkan keluarga yang menderita Skizofrenia untuk minum obat dan mereka juga mengakui bahwa mereka tidak mau mengajak keluarga yang menderita Skizofrenia berbicara karena menurut mereka "tidak nyambung" pada saat diajak berbicara.

Berdasarkan latar belakang diatas, peneliti tertarik untuk melakukan penelitian yang berjudul "hubungan komunikasi dan gukungan sosial keluarga terhadap kekambuhan pasien skizofrenia di Poliklinik Rumah Sakit Jiwa Tampan Pekanbaru Tahun 2017".

\section{METODE PENELITIAN}

Jenis penelitian yang digunakan adalah kuantitatif dengan desain cross sectional, dengan populasi adalah seluruh keluarga pasien skizofrenia dengan jumlah sampel sebanyak 100 orang Pengambilan sampel 
Yecy Anggreny ${ }^{1}$ Sodry $^{2}$, Bayu Saputra ${ }^{3}$, Hubungan Komunikasi Dan Dukungan Sosial Keluarga Terhadap Kekambuhan Pasien Skizofrenia Di Poli Klinik Rumah Sakit Jiwa Tampan Pekanbaru Provinsi Riau

menggunakan teknik Accidental Sampling. terhadap kekambuhan pasien skizofrenia. Alat pengumpulan data menggunakan Responden dalam penelitian ini adalah kuesioner dan analisa data dilakukan secara keluarga pasien, dengan jumlah sampel univariat dan bivariat. sebanyak 100 orang.

\section{HASIL PENELITIAN}

Hasil dari penelitian tentang hubungan komunikasi dan dukungan sosial keluarga

\section{Analisa Univariat}

\section{Karakteristik Responden}

Tabel 4.1

Distribusi Frekuensi Responden Berdasarkan Karakteristik di Poli Klinik Rumah Sakit Jiwa Tampan Pekanbaru Provinsi Riau

\begin{tabular}{|c|c|c|c|}
\hline No & Karakteristik & $\mathbf{F}$ & $\%$ \\
\hline \multirow[t]{5}{*}{1} & Usia & & \\
\hline & 25-35 tahun (dewasa muda) & 18 & 18,0 \\
\hline & 36-45 tahun (dewasa menengah) & 69 & 69,0 \\
\hline & 46-60 tahun (dewasa akhir) & 13 & 13,0 \\
\hline & Total & 100 & 100 \\
\hline \multirow[t]{6}{*}{2} & Hubungan dengan pasien & & \\
\hline & Anak kandung & 42 & 42,0 \\
\hline & Kakak & 20 & 20,0 \\
\hline & Adik & 28 & 28,0 \\
\hline & Pasutri & 10 & 10,0 \\
\hline & Total & 100 & 100 \\
\hline \multirow[t]{6}{*}{3} & Pendidikan & & \\
\hline & SD & 7 & 7,0 \\
\hline & SMP & 20 & 20,0 \\
\hline & SMA & 67 & 67,0 \\
\hline & Perguruan Tinggi (DI/D2/D3/S1/S2/S3) & 6 & 6,0 \\
\hline & Total & 100 & 100 \\
\hline \multirow[t]{4}{*}{4} & Pekerjaan & & \\
\hline & Tidak bekerja & 80 & 80,0 \\
\hline & Bekerja & 20 & 20,0 \\
\hline & Total & 100 & 100 \\
\hline \multirow[t]{4}{*}{5} & Jenis kelamin & & \\
\hline & Laki-laki & 40 & 40,0 \\
\hline & Perempuan & 60 & 60,0 \\
\hline & Total & 100 & 100 \\
\hline
\end{tabular}

Berdasarkan tabel 4.1 karakteristik responden diatas dapat dilihat dari 100 responden pada penelitian ini didapatkan sebagian besar responden dalam kelompok usia 36-45 tahun sebanyak 69 orang $(69,0 \%)$ responden yang memiliki hubungan keluarga sebagai anak kandung sebanyak 42 orang (42,0\%), untuk tingkat pendidikan sebagian besar responden berpendidikan SMA yaitu sebanyak 67 orang $(67,0 \%)$, untuk status 
pekerjaan sebagian besar responden tidak berjenis kelamin perempuan sebanyak 60 bekerja yaitu sebanyak 80 orang $(80,0 \%)$, dan orang $(60,0 \%)$.

untuk jenis kelamin sebagian besar responden

\section{Variabel Penelitian}

Tabel 4.2

Distribusi Frekuensi Responden Berdasarkan Komunikasi Dan Dukungan Sosial Keluarga Dan Kekambuhan Pasien Skizofrenia Di Poli Klinik Rumah Sakit Jiwa Tampan Pekanbaru Provinsi Riau

\begin{tabular}{|c|c|c|c|}
\hline No & Variabel & $\mathbf{F}$ & $\%$ \\
\hline \multirow[t]{4}{*}{1} & Komunikasi & & \\
\hline & Baik & 66 & 66,0 \\
\hline & Kurang & 34 & 34,0 \\
\hline & Total & 100 & 100 \\
\hline \multirow[t]{4}{*}{2} & Dukungan keluarga & & \\
\hline & Baik & 62 & 62,0 \\
\hline & Kurang & 38 & 38,0 \\
\hline & Total & 100 & 100 \\
\hline \multirow[t]{4}{*}{3} & Kekambuhan & & \\
\hline & Tidak sering & 67 & 67,0 \\
\hline & Sering & 33 & 33,0 \\
\hline & Total & 100 & 100 \\
\hline
\end{tabular}

Berdasarkan tabel 4.2 diatas dapat dilihat dari 100 responden pada penelitian ini didapatkan lebih dari separuh responden memiliki komunikasi yang baik yaitu sebanyak 66 orang $(66,0 \%)$, lebih dari separuh

\section{Analisa Bivariat}

Tabel 4.3

Hubungan Komunikasi Terhadap Kekambuhan Pasien Skizofrenia

\begin{tabular}{|c|c|c|c|c|c|c|c|c|}
\hline \multirow[t]{3}{*}{ Komunikasi } & \multicolumn{4}{|c|}{ Kekambuhan } & \multirow{2}{*}{\multicolumn{2}{|c|}{ Total }} & \multirow{3}{*}{ P.value } & \multirow{3}{*}{ Odd Ratio } \\
\hline & Tidak & $\%$ & Sering & $\%$ & & & & \\
\hline & $\mathbf{N}$ & & $\mathbf{N}$ & & $\mathbf{N}$ & $\%$ & & \\
\hline Baik & 50 & 75,8 & 16 & 24,2 & 66 & 100 & 0,018 & $3,125(1,300-7,510)$ \\
\hline Kurang & 17 & 50,0 & 17 & 50,0 & 34 & 100 & & \\
\hline Total & 67 & 67,0 & 33 & 33,0 & 100 & 100 & & \\
\hline
\end{tabular}

Berdasarkan tabel 4.3 diatas diketahui dari 100 responden didapatkan sebanyak 66 orang yang memiliki komunikasi baik terdapat sebanyak 50 orang $(75,8 \%)$ yang tidak sering mengalami kekambuhan, sedangkan dari 34 responden memiliki dukungan sosial keluarga yang baik yaitu sebanyak 62 orang $(62,0 \%)$, dan lebih dari separuh pasien mengalami kekambuhan yang tidak sering yaitu sebanyak 67 orang $(67,0 \%)$. 
Yecy Anggreny ${ }^{1}$, Sodry $^{2}$, Bayu Saputra ${ }^{3}$, Hubungan Komunikasi Dan Dukungan Sosial Keluarga Terhadap Kekambuhan Pasien Skizofrenia Di Poli Klinik Rumah Sakit Jiwa Tampan Pekanbaru Provinsi Riau

komunikasi terhadap kekambuhan pasien komunikasi yang kurang berisiko 3 kali sering skizofrenia, dengan nilai Odd Ratio $(\mathrm{OR})=$ mengalami kekambuhan.

3,125 yang artinya responden yang memiliki

\section{Tabel 4.4}

Hubungan Antara Dukungan Sosial Keluarga Terhadap Kekambuhan Pasien Skizofrenia Di Poli Klinik Rumah Sakit Jiwa Tampan Pekanbaru Provinsi Riau

\begin{tabular}{ccccccccc}
\hline $\begin{array}{c}\text { Dukungan } \\
\text { Sosial } \\
\text { Keluarga }\end{array}$ & \multicolumn{9}{c}{ Kekambuhan } & $\begin{array}{c}\text { Tidak } \\
\text { sering }\end{array}$ & $\mathbf{\%}$ & Sering & $\mathbf{\%}$ & & Total & p.value & Odd Ratio \\
& $\mathbf{N}$ & & $\mathbf{N}$ & & $\mathbf{N}$ & $\mathbf{\%}$ & & \\
\hline Baik & 48 & 77,4 & 14 & 22,6 & 62 & 100 & 0,009 & 3,429 \\
Kurang & 19 & 50,0 & 19 & 50,0 & 38 & 100 & & $(1,435-8,193)$ \\
\hline Total & 67 & 67,0 & 33 & 33,0 & 100 & 100 & & \\
\hline
\end{tabular}

Berdasarkan tabel 4.4 diatas diketahui dari 100 responden didapatkan sebanyak 62 orang yang memiliki dukungan sosial keluarga baik terdapat sebanyak 48 orang $(77,4 \%)$ yang tidak sering mengalami kekambuhan, sedangkan dari 38 orang yang memiliki dukungan sosial keluarga kurang terdapat 19 orang $(50,0 \%)$ tidak sering mengalami kekambuhan. Hasil uji chi square di dapat $p_{\text {value }}=0,009$ lebih kecil dari alpa $=0,05$ hal ini berarti ada hubungan antara dukungan sosial keluarga terhadap kekambuhan pasien skizofrenia, dengan nilai Odd Ratio $(\mathrm{OR})=$ 3,429 yang artinya responden yang memiliki dukungan sosial keluarga yang kurang berisiko 3 kali sering mengalami kekambuhan.

\section{PEMBAHASAN}

\section{Univariat}

\section{a. Komunikasi}

Berdasarkan hasil penelitian ini didapatkan lebih dari separuh responden memiliki komunikasi yang baik yaitu sebanyak 66 orang $(66,0 \%)$. Hal ini menggambarkan bahwa banyak responden menggunakan komunikasi yang baik kepada pasien skizofrenia. Hal ini didukung oleh hasil penelitian yang dilakukan oleh Yunita (2013), di RSJD Puri Nirmala Yogyakarta, menyatakan bahwa $76 \%$ keluarga memiliki pola komunikasi yang baik dengan pasien skizofrenia.

Menurut Machfoedz, (2009), bahwa pola komunikasi yang baik dapat membantu mengurangi kekambuhan pada pasien skizofrenia. Sedangkan menurut Ibrahim (2010), cara berkomunikasi dapat dipengaruhi oleh karakteristik seseorang. Orang yang berpendidikan tinggi memiliki komunikasi yang baik dibandingkan dengan orang yang berpendidikan rendah, begitu pula halnya dengan pekerjaan.

Menurut asumsi peneliti, banyak responden yang memiliki komunikasi yang baik terhadap pasien skizofrenia, hal ini didukung dari hasil kuesioner, dimana banyak responden yang menyatakan mereka jarang membantah apapun yang dikatakan oleh 
pasien pada saat sedang bercerita dan responden sering memandang mata pasien dan mempertahankan kontak mata saat bicara, sehingga pasien merasa diperhatikan dan dihargai oleh keluarga dan tidak menimbulkan kecurigaan dan pasien tidak berisiko mengalami kekambuhan, dengan demikian peneliti menyimpulkan bahwa banyak responden yang memiliki komunikasi yang baik dengan pasien skizofrenia. Selain itu, hal ini yang mendukung komunikasi responden yang baik adalah karakteristik responden itu sendiri, dimana lebih dari separuh responden dengan status pendidikan SMA, sehingga mereka lebih mudah memperoleh informasi dari petugas kesehatan tentang cara berkomunikasi dengan pasien. Selain status pendidikan, usia, pekerjaan akan mempengaruhi komunikasi yang diberikan kepada pasien skizofrenia.

\section{b. Dukungan Sosial Keluarga}

Berdasarkan hasil penelitian ini didapatkan sebagian besar dukungan keluarga yang baik yaitu sebanyak 62 orang $(62,0 \%)$. Hal ini menggambarkan bahwa banyak responden yang memberikan dukungan yang baik kepada pasien skizofrenia. Hal ini didukung oleh hasil penelitian yang dilakukan oleh Yunita (2013), di RSJD Puri Nirmala Yogyakarta, menyatakan bahwa 54\% keluarga memberikan dukungan keluarga yang baik dengan pasien skizofrenia.

Menurut Setiadi (2008), dukungan sosial keluarga sangat penting dalam merawat pasien skizofrenia. Dukungan sosial keluarga meliputi dukungan emosional yang merupakan dukungan dari keluarga yang memberikan individu perasaan nyaman, merasa dicintai saat mengalami depresi, bantuan dalam bentuk semangat, empati, rasa percaya, perhatian sehingga individu yang menerimanya merasa berharga. Pada dukungan emosional ini keluarga menyediakan tempat istirahat dan memberikan semangat. Selain itu dukungan nyata yang meliputi penyediaan dukungan jasmaniah seperti pelayanan, bantuan finansial dan material berupa bantuan nyata (instrumental support material support), termasuk menjaga dan merawat saat sakit termasuk mengawasi pasien minum obat ataupun membantu memecahkan masalah saat pasien mengalami depresi.

Menurut asumsi peneliti, dukungan sosial keluarga yang paling menonjol dalam penelitian ini adalah dukungan emosional dan dukungan nyata, hal ini didukung dari hasil kuesioner bahwa banyak responden yang merasakan cemas dan keyakinan yang tidak sesuai dengan kenyataan dan gangguan persepsi, selain itu responden juga bertanggung jawab terhadap kesehatan pasien skizofrenia dari mulai pengobatan hingga perawatan dirumah, sehingga pasien merasa benar-benar mendapatkan dukungan dari keluarga. Selain itu dari pengisian kuesioner juga diperoleh data bahwa responden jarang membiarkan pasien minum obat sendiri tanpa diawasi keluarga lainnya. 
Yecy Anggreny ${ }^{1}$, Sodry $^{2}$, Bayu Saputra ${ }^{3}$, Hubungan Komunikasi Dan Dukungan Sosial Keluarga Terhadap Kekambuhan Pasien Skizofrenia Di Poli Klinik Rumah Sakit Jiwa Tampan Pekanbaru Provinsi Riau

\section{c. Kekambuhan Skizofrenia}

Berdasarkan hasil penelitian ini sebagian besar responden memiliki kekambuhan yang tidak sering yaitu sebanyak 67 orang $(67,0 \%)$. Hal ini menggambarkan bahwa banyak pasien skizofrenia yang tidak sering mengalami kekambuhan. Hal ini didukung oleh hasil penelitian yang dilakukan oleh Sujarwo \& Supriyadi (2011), di Poliklinik Kesehatan Jiwa Sumatra Utara, menyatakan bahwa $48 \%$ pasien skizofrenia mengalami kekambuhan $<2$ kali dalam 1 bulan.

Menurut Kaplan \& Sadock's (2003), bahwa kekambuhan pasien skizofrenia disebabkan oleh karena komunikasi yang kurang baik dan dukungan sosial keluarga yang kurang. Penderita dengan skizofrenia dapat mengalami kekambuhan kembali, kekambuhan itu bisa saja muncul kembali dalam waktu yang cukup lama, maka dari itu skizofrenia ini disebut juga dengan penyakit kronis. Oleh karena itu penderita skizofrenia perlu mendapatkan perhatian medis.

Menurut asumsi peneliti banyak responden yang menyatakan pasien skizofrenia jarang mengalami kekambuhan. Hal ini didukung dari hasil pengisian kuesioner dimana mayoritas responden memiliki komunikasi dan dukungan sosial keluarga yang baik dengan pasien, sehingga pasien tidak mudah mengalami stres atau depresi yang memicu kekambuhan. Selain itu, hal ini didukung dari data karakteristik responden dimana mayoritas responden adalah berjenis kelamin perempuan, ditambah dengan pekerjaan responden adalah ibu rumah tangga dan hubungan dengan keluarga adalah anak kandung, hal ini dapat memaksimalkan komunikasi dan dukungan keluarga dalam merawat pasien skizofrenia, sehingga mereka baik dalam berkomunikasi dan lebih sabar dalam merawat pasien skizofrenia, seperti memperhatikan minum obat dan melakukan pemeriksaan rutin.

\section{Bivariat}

\section{a. Hubungan Komunikasi dengan \\ Kekambuhan}

Berdasarkan hasil penelitian hasil uji chi square di dapat $p_{\text {value }}=0,018$ lebih kecil dari alpa $=0,05$ hal ini berarti ada hubungan antara komunikasi terhadap kekambuhan pasien skizofrenia, dengan nilai $\mathrm{OR}=3,125$ yang artinya responden yang memiliki komunikasi yang kurang berisiko 3 kali sering mengalami kekambuhan. Menurut Wiramihardja, (2007), bahwa salah satu hal yang sering menimbulkan kekambuhan tersebut salah satunya adalah komunikasi keluarga kepada pasien skizofrenia. Komunikasi yang menyimpang dalam keluarga seperti dengan nada tinggi dan menyinggung perasaan pasien skizofrenia, hal ini sangat berpeluang untuk munculnya gejala kekambuhan pada pasien skizofrenia. Keluarga dari orang dengan skizofrenia menunjukan tingkat penyimpangan komunikasi yang lebih tinggi dibandingkan dengan keluarga yang tidak memiliki anggota keluarga dengan skizofrenia. 
Menurut Fajrina (2012), menyimpulkan bahwa pasien Skizofrenia yang tinggal bersama keluarga yang penuh kritik atau menggunakan kalimat yang berbelit-belit ketika berkomunikasi lebih sering mengalami kekambuhan.

Hasil penelitian ini menyatakan bahwa adanya hubungan antara komuniasi dengan kekambuhan pasien skizofrenia disebabkan karena banyak responden yang menyatakan mereka melakukan komunikasi yang baik dengan pasien. Hal ini didukung oleh hasil penelitian yang dilakukan oleh Yunita (2013), di RSJD Puri Nirmala Yogyakarta, menyatakan bahwa terdapat hubungan antara pola komunikasi dengan frekuensi kekambuhan pasien skizofrenia. Selain itu didukung oleh teori Machfoedz, (2009), bahwa pola komunikasi yang baik dapat membantu mengurangi kekambuhan pada pasien skizofrenia.

\section{Menurut Copel (2007), bahwa} kekambuhan pasien Skizofrenia sering kali disebabkan oleh karena komunikasi, untuk itu ada beberapa cara berkomunikasi yang baik dengan pasien Skizofrenia, salah satunya adalah jangan menghakimi, membantah, atau menggunakan logika untuk menunjukan kekeliruan dalam waham atau halusinasi klien. Menurut Stuart (2006), bahwa komunikasi yang baik yang didapat diterapkan kepada pasien Skizofrenia, seperti dengan mempertahankan kontak mata, tersenyum dan memasang wajah yang positif saat saling berkomunikasi, dan bersikap netral jika pasien tidak mau diajak bicara.

Berdasarkan hasil penelitian dapat disimpulkan bahwa komunikasi responden baik terhadap pasien skizofrenia. Hal ini didukung dari hasil kuesioner dimana banyak responden menyatakan bahwa mereka tidak pernah menghakimi pasien apabila berbuat salah. Selain itu dari indikator menggunakan metode non verbal, banyak responden yang menyatakan bahwa mereka selalu memandang mata pasien saat berbicara, agar pasien tahu bahwa responden mendengarkannya. Sehingga hal ini membuat pasien merasa nyaman dan tidak terganggu dan tidak membuat pasien mengalami kekambuhan.

\section{b. Hubungan Dukungan Sosial Keluarga dengan Kekambuhan}

Berdasarkan hasil penelitian hasil uji chi square di dapat $p_{\text {value }}=0,009$ lebih kecil dari alpa $=0,05$ hal ini berarti ada hubungan antara dukungan keluarga terhadap kekambuhan pasien skizofrenia, dengan nilai $\mathrm{OR}=3,429$ yang artinya responden yang memiliki dukungan keluarga yang kurang berisiko 3 kali sering mengalami kekambuhan. Menurut Rothrock (2009), bahwa dukungan sosial dari keluarga dapat mempengaruhi tingkat kekambuhan pasien skizofrenia.

Menurut Taufik (2009), dengan hasil terdapat hubungan dukungan keluarga dengan tingkat kekambuhan pasien Skizofrenia. Menurut penelitian yang dilakukan oleh Yunita (2013), di RSJD Puri Nirmala Yogyakarta, menyatakan bahwa dukungan 
Yecy Anggreny ${ }^{1}$, Sodry $^{2}$, Bayu Saputra ${ }^{3}$, Hubungan Komunikasi Dan Dukungan Sosial Keluarga Terhadap Kekambuhan Pasien Skizofrenia Di Poli Klinik Rumah Sakit Jiwa Tampan Pekanbaru Provinsi Riau

sosial juga dapat mempengaruhi kekambuhan pasien Skizofrenia.

Menurut Setiadi (2008), bahwa dukungan emosional dari keluarga dapat memberikan perasaan nyaman pada pasien skizofrenia, mereka merasa dicintai saat mengalami depresi, bantuan dalam bentuk semangat, empati, rasa percaya, perhatian sehingga individu yang menerimanya merasa berharga. Selain itu dukungan nyata dari keluarga yang meliputi penyediaan dukungan jasmaniah seperti pelayanan, bantuan finansial dan material berupa bantuan nyata (instrumental support material support), termasuk menjaga dan merawat saat sakit termasuk mengawasi pasien minum obat ataupun membantu memecahkan masalah saat pasien mengalami depresi.

Menurut Aswat (2009), dukungan sosial keluarga dapat dipengaruhi oleh faktor karakteristik seseorang, salah satunya adalah jenis kelamin. Jenis kelamin mempengaruhi perilaku kehidupan manusia. Perilaku seorang perempuan tidak sama dengan perilaku lakilaki. Perempuan lebih memiliki kelembutan dan kasih sayang. Sedangkan laki-laki cenderung memiliki sikap ego dan mementingkan dirinya sendiri.

Berdasarkan dari hasil penelitian dapat disimpulkan bahwa dukungan sosial keluarga yang diberikan pada pasien skizofrenia baik. Hal ini didukung dari pengisian kuesioner juga diperoleh data bahwa responden jarang membiarkan pasien minum obat sendiri tanpa diawasi keluarga lainnya. 


\section{SARAN}

a. Diharapkan dengan adanya penelitian ini dapat mempertahankan dan meningkatkan pengetahuan keluarga tentang cara komunikasi dan aplikasi serta memberikan dukungan sosial keluarga kepada pasien skizofrenia.

b. Diharapkan bagi instansi RSJ Tampan Pekanbaru dapat menerapkan kepada seluruh perawat untuk menggunakan komunikasi serta memberikan dukungan sosial yang baik kepada pasien skizofrenia.

c. Diharapkan bagi perawat di RSJ Tampan Pekanbaru dapat memberikan edukasi kepada keluarga pasien skizofrenia tentang pentingnya penggunaan komunikasi serta pemberian dukungan sosial yang baik kepada pasien skizofrenia yang bertujuan untuk menurunkan kejadian kekambuhan pasien skizofrenia, serta memperbaiki metal pasien skizofrenia.

d. Diharapkan bagi peneliti lain untuk dapat melanjutkan penelitian tentang masalah kekambuhan pasien skizofrenia, dan diharapkan peneliti selanjutnya dapat menggunakan metode observasi untuk setiap variabel penelitian dan dengan menggunakan analisa multivariat, agar diketahui faktor-faktor apasaja yang berhubungan dengan kekambuhan pasien skizofrenia.

\section{DAFTAR PUSTAKA}

Aswat, (2009). Pengantar Perilaku Kesehatan , Edisi ketiga. Jakarta: Binarupa Aksara,

Copel, L. (2007), Kesehatan jiwa dan psikiatri. Jakarta: ECG.

Fajrina (2012), Gambaran dukungan keluarga pada pasien skizofrenia yang mengalami kekambuhan di RSJ Pemerintah Aceh. http://etd.unsyiah.ac.id/index.php?p=sho w_detail\&id=18058.

Ibrahim, (2010). Komunikasi keluarga. Jakarta: Binajaya.

Kaplan \& Sadock's, (2003). Kesehatan jiwa. Jakarta: Edu Pustaka

Machfoedz, (2009). Komunikasi keperawatan teraupetik. Yogyakarta: Ganbika.

Profil Kesehatan Provinsi Riau, (2015). Data skizifrenia. Tidak diPublikasikan.

Riskesdas, (2013). Kasus skizofrenia di Indonesia. Diakses pada tanggal 12 Desember 2016. Diperoleh dari https://www.tempo.co/topik/lembaga/40 9/kasus_skizofrenia_di_Indonesia.

Rothrock (2009), Perencanaan asuhan keperawatan perioperatif. Jakarta: ECG.

Setiadi, (2008). Konsep dan praktik penulisan riset keperawatan. Jakarta: Graha Ilmu.

Stuart, G. (2006). Buku saku keperawatan jiwa. Jakarta: ECG.

Stuart, G. (2006). Buku saku keperawatan jiwa. Jakarta: ECG.

Stuart, G. (2006). Buku saku keperawatan jiwa. Jakarta: ECG.

Sujarwo \& Supriyadi, (2011). hubungan antara frekuensi kekambugan pada pasien skizofrenia dengan tingkat kecemasan pada keluarga di RSJD Dr. Amino Gondohutomo Semarang. STIKes Telogorejo Semarang.

Taufik, Y. (2014), Hubungan dukungan keluarga dengan tingkat kekambuhan pada pasien skizofrenia di Poliklinik RSJ Grhasia Yogyakarta. Diperoleh dari jurnal STIKes Asyiyah.,Vol 05 Nomor 02., Yogyakarta.

Wiramihardja, (2007). Pengantar psikologi klinis. Jakarta: ECG.

Yosep \& Sutini, (2015). Buku Ajar Keperawatan Jiwa. Jakarta: Agrama

Yunita, P. (2013). Hubungan pola komunikasi dengan tingkat kekambuhan pasien skizofrenia di RSJ Puri Nirmala 
Yecy Anggreny ${ }^{1}$ Sodry $^{2}$, Bayu Saputra ${ }^{3}$, Hubungan Komunikasi Dan Dukungan Sosial Keluarga Terhadap Kekambuhan Pasien Skizofrenia Di Poli Klinik Rumah Sakit Jiwa Tampan Pekanbaru Provinsi Riau

Yogyakarta. Diperoleh dari jurnal

UGM., Vol 02 Nomor 03., Yogyakarta. 